İş ve İnsan Dergisi | The Journal of Human and Work

Y1l | Year: Nisan | April 2015

Cilt-Sayı | Volume-Issue: 2 (1)

ss | pp: 1-11

doi: 10.18394/iid.90685

e-ISSN 2148-967X

http://dergipark.ulakbim.gov.tr/iid/

Araştırma Makalesi

\title{
Yöneticilerin Algılanan Kültürel Zekâsı, Çalışanın Farklılık İklimi Algısı, Gelişime Açıklık ve Örgütsel Sinisizm Etkileşimi Üzerine Turizm Sektöründe Bir Araştırma
}

\section{The Relationship among Leaders' Perceived Cultural Intelligence, Employees' Diversity Climate Perception, Employees' Openness to Experience and Organizational Cynicism: A Research in Tourism Sector}

\author{
Sezer Cihan Çalışkan \\ Haliç Üniversitesi
}

\section{Zeynep Merve Ünal \\ Marmara Üniversitesi}

\author{
Yaprak Kalafatoğlu \\ Marmara Üniversitesi
}

\author{
Ciğdem Üçler \\ Marmara Üniversitesi
}

\author{
F. Aslı Akün \\ İstanbul Üniversitesi
}

MAKALE BİLGİSI

Anahtar Kelimeler:

Kültürel Zekâ, Farklılık

Iklimi Algısı, Gelişime

Açıklık, Örgütsel Sinisizm,

Farklılı Yönetimi.

\section{Tarihler:}

Geliş 28 Kasım 2014

Düzeltme geliş 26 Aralık

2014

Kabul 30 Aralık 2014

\section{ARTICLE INFO}

\section{Keywords:}

Cultural Intelligence,

Diversity Climate

Perception, Openness to

Experience, Organizational

Cynicism, Diversity

Management.

\section{Article history:}

Received 28 November 2014

Received in revised form 26

December 2014

Accepted 30 December 2014
ÖZ
Bu araștırmanın amacı, yöneticilerin algılanan kültürel zekâsı, çalışanların farklılık iklimi algısı ve çalışanların deneyime açıklık özelliklerini araştırmak, olumsuz çalışan davranışı olarak adlandırllan sinisizm üzerindeki etkilerini açılamak ve farklılıkların yönetiminin önemine değinmektir. Veriler, otellerde çalışan 160 kişiden anket yöntemiyle toplanmıştır. Anket formu, kültürel zekâ, örgütsel sinisizm, farklılık iklimi algısı ve deneyime açıklık ölçeği ile demografik soruları kapsamıştır. Değişkenler arasındaki ilişkiler, korelasyon ve regresyon analizi yöntemiyle incelenmiştir. Araştırma bulguları, çalışan farklılık iklimi algısının yöneticilerin algılanan kültürel zekâsı ile örgütsel sinisizm arasındaki ilișkide aracı değisken olduğunu göstermistir. Calışanın gelișime açılık seviyesinin yöneticilerin algllanan kültürel zekâsıyla farklılık iklimi algısı arasındaki şartlı değişken etkisi bulgulanmamıştır. Çalışmanın kuramsal açıdan önemi, yöneticinin algllanan kültürel zekâsının örgütsel sinisizm üzerindeki etkisinin bütüncül bir modelde incelenmesi ve çallşanın farklllı iklimi algısının aracı değişken olarak test edilmesidir. Bu hususta araştırmamız özgün bir nitelik taşımaktadır. Insan kaynakları uygulamalarılla çalışanlarda kültürel zekâ geliştirilmesi ve süreçlerde farklılıkların etkili yönetiminin sağlanması çalışmanın pratik anlamda sunduğu çözümlerdendir.

\begin{abstract}
A B S T R ACT
This study aims; to explore leaders' perceived cultural intelligence, employees' diversity climate perception and employees' openness to experience; investigate their effects on organizational cynicism as a negative employee behavior and to emphasize the importance of diversity management. Data were collected from 160 employees working at hotels using a survey instrument. The structured survey instrument included measurements of cultural intelligence, diversity climate perception, organizational cynicism, openness to experience, and several demographic items. To identify the relationship among the study variables, correlation and regression analysis were conducted. The results of the study suggested that employees' organizational climate perception mediates the relationship between leaders' cultural intelligence and organizational cynicism. Employees' openness to experience did not have a moderating effect on the relationship between leaders' perceived cultural intelligence and employees' diversity climate perception. This study provides a unique theoretical contribution by examining the effect of leaders' perceived cultural intelligence on cynicism in a comprehensive model and testing employees' diversity climate perception as a mediating variable. Developing cultural intelligence of employees and managing diversity effectively in organizations through human resources practices are among the practical solutions of the study.
\end{abstract}

\footnotetext{
Bu makale, 07-08 Kasım 2014 tarihlerinde Kayseri'de yapılan 2. Örgütsel Davranış Kongresi'nde sunulmuş bildirinin genişletilmiş halidir.

* Iletişim kurulacak yazar: Yaprak Kalafatoğlu, Araştırma Görevlisi, Marmara Üniversitesi, İşletme Fakültesi, İngilizce İşletme Bölümü, Örgütsel Davranış Anabilim Dalı, İstanbul, Türkiye. E-posta: yaprak.kalafatoglu@ marmara.edu.tr
} 


\section{GİRIŞ}

Günümüzde küreselleşme neticesindeki şirket birleşmeleri ve yabancı sermayeli işletmelerin kurulması farklılık yönetimi konusunun daha çok gündeme gelmesine neden olmuş ve farklı kültürlerden daha çok kişinin bir arada etkili bir biçimde çalışmasını zorunlu kılmıştır. İşletmeler açısından "farklılıklar" bireyleri birbirlerinden farklılaştıran veya onları benzer kılan, kişiye özgü içsel ve dışsal bütün özellikleri ifade etmekte ve "insanlar arasında, 1rk, kültür, cinsiyet, cinsel yönelim, yaş ve fiziksel yeterlilikler gibi bir takım nitelikler açısından var olan farklar" şeklinde tanımlanmaktadır (Sürgevil ve Budak, 2008). Bu çeşitliliği içinde barındıran iş ortamları da kişiler arası ilişkilerinde farklılıklara yönelik bilgilerini kullanabilecek birikime sahip olan yöneticilere ihtiyaç duyacaklardır. Buna yönelik, yöneticilerin yapıcı davranışları çalışanlar tarafindan algılandığında, buna bağlı uygulamalar çalışanların örgütsel bütüne uyum sağlamalarına ve olumlu bir farklılık iklimi algısına sahip olmalarına neden olabilecektir. İnsanların cinsiyeti, dini, yöresi ve bedensel engeli gibi farklılıkların vurgulandığ kurumlarda çalışanların örgüte karşı sinik davranışlarda bulunması kaçınılmaz olacaktır. Yazında farklılık iklimi algısının örgütsel sinisizm üzerindeki etkisini inceleyen bir çalışma henüz bulunmamaktadır. Hâlbuki bireysel farklılıkları nedeni ile kendini değersiz hisseden negatif farklılık iklimi algısına sahip çalışanların, bu değersizlik ve adaletsizlik duyguları nedeni ile bilişsel, duygusal ve davranışsal olarak çalıştıkları örgüte ve diğer bireylere sinik tutumlar göstermesi mümkündür. $\mathrm{Bu}$ öngörünün deneysel çalışmalar ile de test edilmesinin teorik anlamda ve uygulamada yazına katkı sağlayacağı kanısındayız.

\section{KURAMSAL ÇERÇEVE VE HİPOTEZLER}

\subsection{Kuramsal Çerçeve}

2.1.1. Kültürel Zekâ: Kültürel zekâ konusu yabancı yazında ilk defa Earley ve Ang (2003) tarafindan ele alınan bir kavramdir. Earley ve Ang (2003) kültürel zekâyı bireyin farklı kültürel ortamlarda etkin bir şekilde çalışması ve farklı kültürel ortamları yönetmesi olarak tanımlamaktadır. Ang ve diğerleri (2007) ise, kültürel zekâyı, farklı kültürel ortamlarda etkin bir şekilde çalışabilme yeteneği olarak tanımlamışlardır. Kültürel zekâ konusunda çalışmalar yapan bir başka yazar Maznevski (1994) ise, kültürel zekâyı, insanın kendisi olmaya çalışırken, aynı zamanda başkalarının kendileri olmalarına izin vermek, onlara sayg1 duymak ve değer vermek olarak tanımlamıştır. Ayrıca kültürel zekâyı, isletmeyle veya kültürle alakalı problemleri anlama ve yönetme yeteneği olarak ifade etmiştir. Maznevski (2006), kültürel zekânın, kültürler hakkında bilgi sahibi olmayı, farklı kültürlerde etkin çalışabilmeyi ayrıca kişinin kendi hareket, davranış, reaksiyon ve öğrenme süreçlerine dikkat edebilmesini gerekli kıldığını vurgulamıştır. Thomas ve Inkson (2005), kültürel zekâyı, bir kültürü anlamada esnek ve yetenekli olmak, artan bir şekilde bu kültür hakkında bilgi sahibi olmak, bu kültürlerle etkileşim halinde iken daha uygun davranış biçimleri geliştirerek adapte olmak ve düşünce yapısını bu bağlamda yavaş yavaş yeniden yapılandırmaya çalışmak olarak tanımlamışlardır.

Earley ve Ang (2003) kültürel zekâyı üst bilişsel kültürel zekâ(farklı kültürel deneyimlere sahip olmak), bilişsel kültürel zekâ (kültürel farklılıklar ve benzerlikler hakkında bilgi sahibi olmak), güdüsel kültürel zekâ (farklı kültürlerde kendine güven duyarak etkili bir biçimde olaylara muamele edebilmek) ve davranışsal kültürel zekâ (farklı kültürlerde uygun davranışlarda bulunabilme esnekliğine sahip olmak) olarak dört alt boyuta ayırmışlardır.

Yazında kültürel zekâ üzerine yapılan çalışmaların 2000'li yılların ortalarından sonra artış gösterdiği görülmektedir. Örneğin Leung, Ang ve Tan (2014) tarafından yapılan kültürlerarası yetkinlik kriterlerinin değerlendirildiği çalışmada kültürel zekânın bireysel, kişilerarası ve grup düzeyinde psikolojik, davranışsal ve performansa dayalı çıktılar üzerindeki etkilerini ele alan çalışmalar incelenmiştir. Yazarlar tarafından aktarıldığı gibi, kültürel zekânın kültürlerarası ve psikolojik uyum, işe uyum ve adaptasyon, psikolojik esenlik, duygusal tükenmişlik, iş ve görev performansı, çok kültürlü takımlarda liderlik performans1, uluslararası liderlik potansiyeli gibi değişkenler üzerindeki etkileri görülmektedir. Türk yazınında Şahin (2011) ve Şahin ve Gürbüz (2012) tarafindan yapılan çalışmalarda da liderin üst bilişsel, motivasyonel ve davranışsal kültürel zekâlarına bağlı olarak astların liderden kaynaklanan iş doyumlarında artış olduğu bulunmuştur. Astların örgütsel vatandaşlık davranışları da, liderin motivasyonel ve davranışsal kültürel zekâ bileşenlerinden olumlu yönde etkilendiği görülmüştür.

$\mathrm{Bu}$ bağlamda, yöneticilerin kültürel zekâ düzeylerinin yüksek olması ve bununla ilişkili olarak çeşitliliğe ilişkin yapıcı yaklaşımlarının ve davranışlarının çalışanlar tarafından algılanması, çalışanların örgütsel bütüne uyum sağlamasına zemin hazırlayabilecektir. Bu da çalışanların olumlu bir farklılık iklimi algısına sahip olmalarına neden olabilecektir. 
2.1.2. Örgütsel Sinisizm: 90’lı yıllarda örgütsel davranış yazınında çalışmalara konu olmaya başlayan örgütsel sinisizm, "bireyin çalıştığı örgüte karş1 geliştirdiği örgütün dürüstlükten yoksun olduğuna dair inanç, örgüte yönelik olumsuz bir duygu ve bu inanç ve duygularla tutarlı olarak örgüte yönelik aşağılayıcı ve eleştirel davranma eğilimi" olarak tanımlanmaktadır (Dean, Brandes ve Dharwadkar, 1998). Yazında olumsuz bir çalışan tutumu olarak ele alınan sinisizmin bilişsel, duygusal ve davranışsal boyutlardan oluştuğu belirtilmektedir. Bilişsel boyutta, "kurumun ve burada çalışan bireylerin dürüstlükten yoksun olduğu inancı" vurgulanmaktadır; örgütsel sinisizmin duygusal boyutu, saygısızlık, öfke, sıkıntı ve utanç duyma gibi kuvvetli duygusal tepkileri kapsamaktadır. Örgütsel sinisizm düzeyleri yüksek bireylerin örgütlerini düşündükleri zaman sıkıntı, tiksinti ve utanç hissedebilecekleri belirtilmektedir. Çalıştıkları kurumda sinik davranışta bulunan çalışanlar, örgüt içinde gelişen olaylar hakkında karamsar tahminler yapma eğiliminde olabilirler. Olumsuz ve çoğu zaman insanı küçük düşürmeye yönelik davranışlarda bulunabilirler. Çalışanların birbirleriyle anlamlı bir biçimde bakışmaları, alaycı gülüşleri ve küçümser bir tavırla gülümsemeleri sinik davranışlara örnek oluşturmaktadır (Dean ve diğerleri, 1998). Yazında örgütsel sinisizmin öncelleri olarak yanlış yönetilen değişim çabaları, yüksek makam tazminatı, düşük örgütsel performans, sert ve çabuk işten çıkarılma duyurusu, yüksek düzeyde rol çatışması, aşırı rol yükü ve tutulmayan sözler ele alınmaktadır. Türkiye'de yapılan benzer çalışmalarda da, örgütsel adalet ve psikolojik sözleşme ihlallerinin sinisizm ile ilişkileri irdelenmiştir (Wanous, Reichers ve Austin, 1994; Tükeltürk, Perçin ve Güzel, 2009). Anderson ve Bateman'a (1997) göre, verimsiz örgüt içi iletişim, adaletsiz ve saygısız kişiler arası ilişkiler ile yönetimsel yetkinliğin olmaması örgütsel sinisizmi yordayan önemli değişkenler olarak bulgulanmıştır.

2.1.3.Farklılık İklimi Algısı: Farklılıkların yönetimi, en yalın şekliyle; çalışan farklılıklarından doğan gerilimi dengelemeye ve bu farklılıklardan avantaj elde etmeye çalışan bir anlayışa işaret etmektedir. Son yıllarda popülerlik kazanarak yazında yer alan ve farklılıkların yönetimi yaklaşımı ile ilgili olan bir diğer kavram da "farklılık İklimi" dir. Bu kavram, örgüt içinde "farklı"olarak nitelendirilenlere karşı örgütün yarattığı firsat ve engellere yönelik algılar bütünü olarak tanımlanmaktadır(Okat, 2010). Örgütler, çalışanların psikolojik olarak olaylara yükledikleri anlamları yansıtan çok sayıda iklime sahiptirler. "Farklılı iklimi" ise örgüt kapsamındaki kadın ve azınlıklar gibi farklı özelliklere sahip olanlarla ilgili algılara dayalı olarak ortaya çıkan çalışan tutum ve davranışlarını yansitmaktadır (Kossek ve Zonia, 1993). Farklık iklimi, örgütte ayrımcılığın ne ölçüde önlendiğini ve farklılığın ne ölçüde sürdürüldüğünü ve güçlendirildiğini dolaylı olarak ya da doğrudan bir şekilde ifade eden yöntem, politika ve uygulamalara yönelik çalışanların ortak algısıdır (Pugh, Brief, Dietz\&Wiley, 2008).

Mead'in (1934) sembolik etkileşim teorisine göre bireyler örgüt içerisindeki sosyal etkileşimlerine dayanarak örgüte anlam yüklemektedirler. Örgüte atfedilen anlam iklim algısının oluşmasına katkıda bulunur (Schneider ve Taylor, 1983). Fiske ve Taylor (1991) ise bireyin sahip olduğu inançları ve farklılığa dair tecrübelerini de farklılık iklimi algısına katkı yapan değişkenler olarak vurgulamışlardır. Örgüt içerisinde bireyler farklılıkları nedeniyle kendilerini değersiz olarak hissederlerse, iş doyumu, kariyer doyumu ve örgütsel bağlılıklarında düşüş ortaya çıkmaktadır (Cox, 1993). Cox’ a (1993) göre, bütün çalışanların desteklendiği, teşvik edildiği ve bütün çalışanların eşit firsatlara sahip olduğu bir iklim yaratan örgütler rakiplerine göre daha iyi bir konuma, daha yaratıcı ve motive olmuş çalışanlara sahip olmaktadırlar. İşyerinde saygı ve itibar gören, eğitim, kariyer ve terfi konularında eşit davranılan ve yöneticilerin her tür ayrımcılığa (ırk ayrımı, cinsiyet ayrımı, yöresel ayrım) engel olduğu kurumlarda olan bireylerin ise işletme üretkenliği ve verimliliğine yönelik olumlu tutumlar içerisine girebilmesi öngörülebilir.

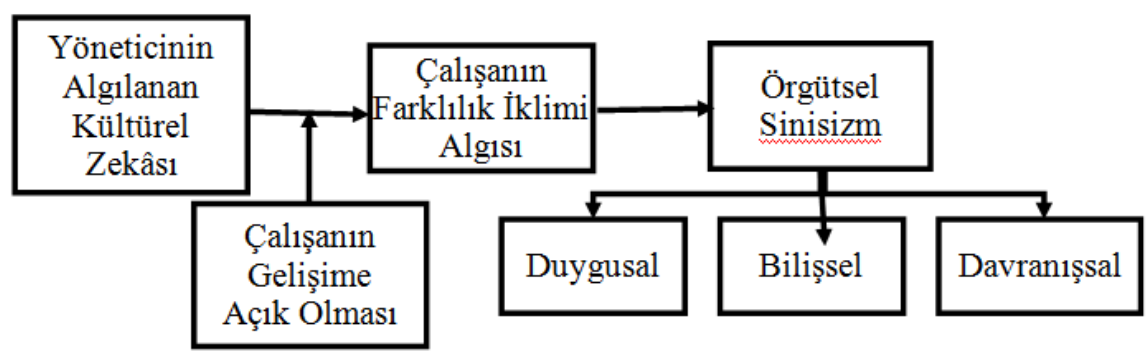

Şekil 1. Araștırmanın teorik modeli 
Farklılık iklimi algısı bu çalışmada "olumlu” bir değişken olarak ele alınmıştır.

2.1.4 .Gelişime Açıklık: Allport ve Odbert'in (1936) kişiliği tanımlayan binlerce sözcüğü dört gruba ayırmasıyla başlayan çalışma çeşitli araştırmacıların (Cattell, 1946; Tupes ve Christal, 1961; Norman, 1963) bu sürece katkısı sonucu McCrae ve Costa'nın (1985a) NEO-PI-R ölçeğindeki gelişime açıklık boyutunu ortaya çıkarmıştır. Yüksek seviyede gelişime açık olan bireyler, hayal kuran, macerasever, özgün, yaratıc1, merakl1, kendi düşünce ve duygularına yönelen bireyler olarak tanımlanmaktadır (Bono vd., 2002; Costa ve McCrae, 1995; Liebert ve Spiegler, 1990). Yazında, gelişime açıklık önyargı ve ırklarla ilgili düşüncelerle (Flynn, 2005), takımların işlevselliğinin gelişimi ile (Homan vd. 2008) ve kültürel zeka ile (Ang, Dyne, ve Koh, 2006) ilişkili bulgulanmıştır.

2.1.5. Yöneticinin Algılanan Kültürel Zekâsı, Çalışanın Farklılık İklimi Algısı, Gelişime Açıklık Seviyesi ve Örgütsel Sinisizm Arasındaki İlişkiler: Yöneticilerin kültürel çeşitliliğe yönelik yapıcı davranışları çalışanlar tarafından algılandığında, buna bağlı uygulamalar çalışanların örgütsel bütüne uyum sağlamalarına ve olumlu bir farklılık iklimi algısı oluşturmalarına katkıda bulunarak kuruma karşı olumsuz tutum ve davranışların azalmasına katkıda bulunacaktır. Bireylerin gelişime açıklık seviyesinin yöneticinin kültürel zekâsı ile çalışanın farklılık iklimi algısı arasındaki ilişkinin gücünü değiştireceği, yani şartlı değişken rolü bulunacağı düşünülmektedir. Yöneticisinin kültürel farklılıkları göz önünde bulundurarak davrandığını algılayan bireylerin olumlu farklılık iklimi algısı artacaktır. Ancak yöneticinin kültürel zekâsının farklılık iklimi algısı üzerindeki katkısının gelişime açık olan bireyler için daha güçlü olacağı düşünülmektedir.

Bu çerçevede araştırmanın teorik modeli Şekil 1'de gösterilmektedir. Buna göre;

Hipotez 1: Çalışanın farklılık iklimi algısı, yöneticinin algılanan kültürel zekâsı ile örgütsel sinisizm arasında ara değişken rolüne sahiptir. (Yöneticinin algılanan kültürel zekâsının katkısıyla artan olumlu farklılık iklimi algısı, örgütsel sinisizmi azaltır).

Hipotez 2: Çalışanın gelişime açıklığı, yöneticinin algılanan kültürel zekası ile farklılık iklimi algısı arasındaki ilişkide düzenleyici değişken rolü üstlenmektedir. Şöyle ki bu düzenleyici etki gelişime açıklık kişilik özelliği yüksek olanlarda bu kişilik özelliği düşük olanlardan daha yüksektir.

\section{YÖNTEM}

\section{1. Örneklem ve Uygulama}

Araştırmaya ait verilen yapılandırılmış anket uygulaması yöntemi ile İstanbul'da bulunan 4 ve 5 yıldızlı çok uluslu otel gruplarının beyaz yakalı

Tablo 1. Kültürel Zekâ Faktör Analizi Sonuçları

\begin{tabular}{|c|c|c|c|c|}
\hline Faktörün Adı & Soru ifadesi & $\begin{array}{c}\text { Faktoör } \\
\text { Ağıuliklan }\end{array}$ & $\begin{array}{c}\text { Faktörūn } \\
\text { Açiklayıcilığı (\%) }\end{array}$ & Güvenilitrik \\
\hline \multirow{5}{*}{$\begin{array}{l}\text { Gũdüsel Kültürel } \\
\text { Zekâ }\end{array}$} & \multirow{5}{*}{ 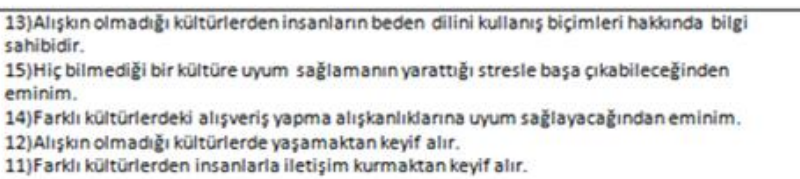 } & 0,760 & \multirow{5}{*}{20,746} & \multirow{5}{*}{0,909} \\
\hline & & 0,747 & & \\
\hline & & 0,739 & & \\
\hline & & 0,686 & & \\
\hline & & 0,669 & & \\
\hline \multirow[t]{5}{*}{$\begin{array}{l}\text { Davranussal } \\
\text { Kültürel Zekâ }\end{array}$} & $\begin{array}{l}\text { 20)F Farkl külttürlerden insanlaria iletişim kurarken, gerekli durumlarda yüz ifadesini } \\
\text { değiştirir. }\end{array}$ & 0,808 & \multirow{5}{*}{20,018} & \multirow{5}{*}{0,915} \\
\hline & $\begin{array}{l}\text { 19)F arklı kültürden insanlarla iletişim kurarken, gerekli durumlarda sesinin tonunu ve } \\
\text { vurgusunu değiștirir. }\end{array}$ & 0,791 & & \\
\hline & 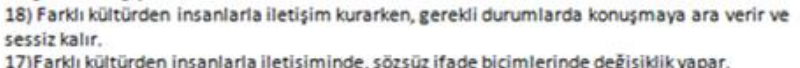 & 0,787 & & \\
\hline & $\begin{array}{l}\text { 16) Farklı kültürden insanlarla iletişim kurarken gerektiğinde sözlü iletişim } \\
\text { ögelerinde(aksan, ton) değ şibliker yapar. }\end{array}$ & 0,733 & & \\
\hline & & 0,673 & & \\
\hline \multirow{5}{*}{$\begin{array}{l}\text { Bilişsel Kültürel } \\
\text { Zekâ }\end{array}$} & 8)Farkıı kültürlerin sanat dallan hakkanda bilgi sahibidir. & 0,844 & \multirow{5}{*}{19,010} & \multirow{5}{*}{0,919} \\
\hline & 7) Farkiı küitürlerin evilik törenleri hakkanda bilgi sahibidir. & 0,840 & & \\
\hline & 6) Farkıı kültürlerin dini inanışlan hakkonda bilgi sahibidir. & 0,694 & & \\
\hline & 10) Diğer kültürlerden insanlann beden dilini kullanus biçimleri hakjanda bilgi sahibidir. & 0,618 & & \\
\hline & 9) Farklı kültürlerin dilleri hakbanda bilgi sahibidir. & 0,604 & & \\
\hline \multirow{8}{*}{$\begin{array}{l}\text { Meta-Bilisssel } \\
\text { Kültürel Zekâ }\end{array}$} & 1)Farkıı kültürel geçmişe sahip insanlarla iletişime geçtiği zaman kültürel bilgilerini kullanır. & 0,806 & \multirow{4}{*}{17,809} & \multirow{4}{*}{0,907} \\
\hline & 2) Kültürlerarası iliş̧ilerinde, farklı kültürlere yönelik bilgilerini kullanır. & 0,797 & & \\
\hline & $\begin{array}{l}\text { 4)Farklı küitürden insanlar ile iletişime geştiğinde, bilgilerinin o kültüre göre uvgun } \\
\text { olduğundan emin olur. }\end{array}$ & 0,689 & & \\
\hline & $\begin{array}{l}\text { 3) Alışın olmadığı kültûrden kişiler ile iletişime geçtiği zaman, bilgilerini o kültüre göre } \\
\text { ayarlar. }\end{array}$ & 0,676 & & \\
\hline & & Toplam & 77,583 & \\
\hline & & кMO & 0,933 & \\
\hline & & Barlett Testi & Kikare & 2737,228 \\
\hline & & & P dežeri & $\begin{array}{l}171 \\
0,000\end{array}$ \\
\hline
\end{tabular}


Tablo 2. Örgütsel Sinisizm Faktör Analizi Sonuçları

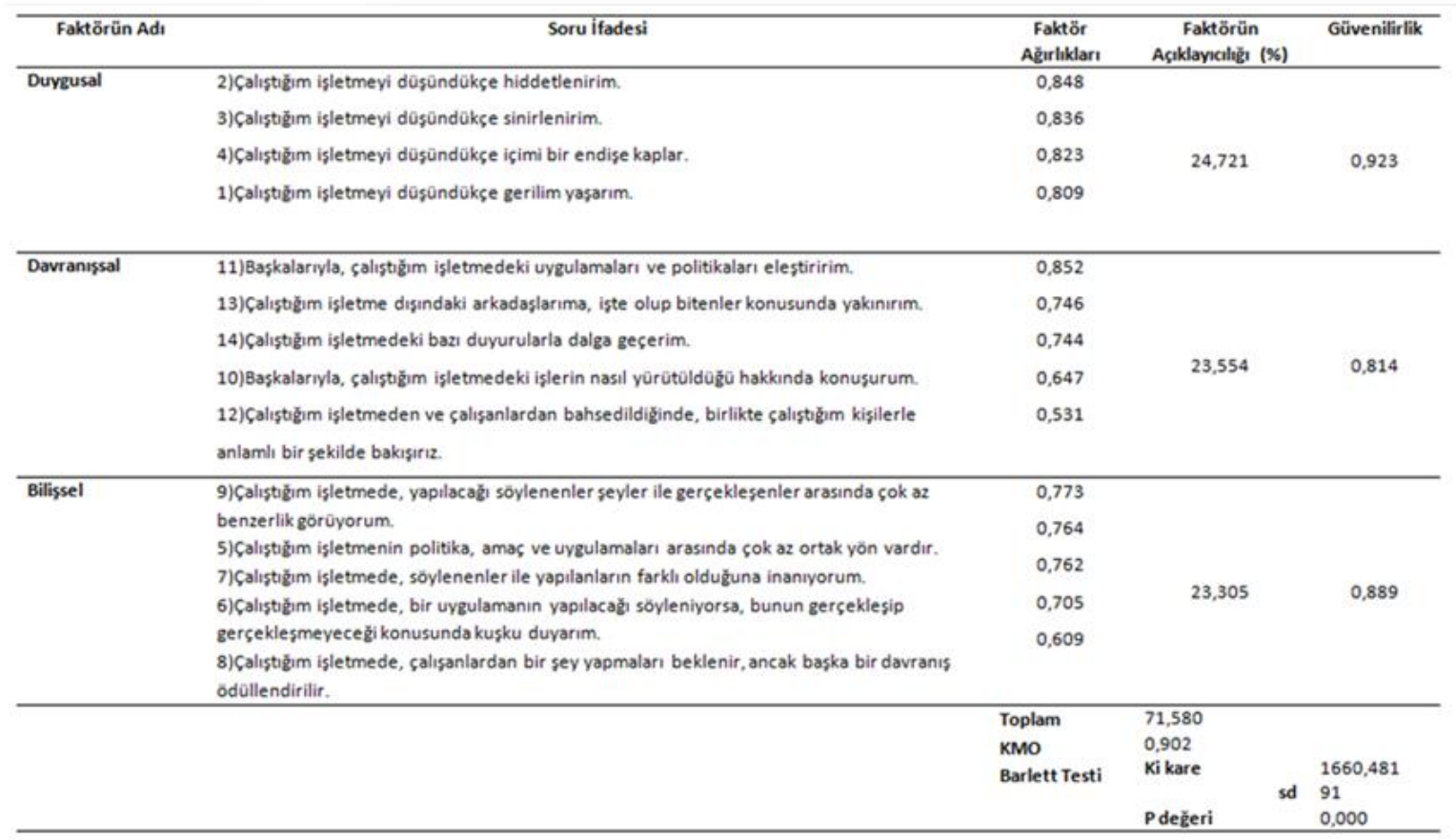

çalışanlarından elde edilmiştir. Araştırmaya 160 çalışan katılmış ve analizler bu veri üzerinden yapılmıştır. Araştırmanın örneklem özelliklerine bakıldığında \%50'sı kadın \%50'si erkektir. Katılımcıların yaşları 19 ile 59 arasında değişmekte olup ortalaması 31'dir. Kat1lımc1ların \%58'si bekâr \%38'i evlidir. Katılımc1ların \%82 si 1-5 y1l, \%16's1 6-10 y1l ve \%2'si 11-16 y1l kıdeme sahiptirler. Veri kolayda örneklem yöntemi ile toplanmıştır. Ölçüm araçlarının katılımcılara dağıtılmasında verilerin toplandığı beş yıldızlı otellerden birinin insan kaynakları direktörü rol oynamıştır. Katılımcılara dağıtılan anketlerin kapak sayfasında araştırmanın amacı anlatılmıştır. Katılımcıların cevaplarının saklı kalıp başka bir amaç için kullanılmayacağına dair bilgi verilmiştir.

\subsection{Kullanılan Ölçüm Araçları}

Araştırmanın amacı doğrultusunda aşağıda açıklanmış ölçüm araçları kullanılmıştır.

3.2.1. Kültürel Zekâ Ölçeği: Modelin bağımsız değişkeni olan yöneticinin algılanan kültürel zekâsını ölçmek üzere Ang ve diğerleri (2007) tarafından geliştirilen 20 maddelik ölçek kullanılmıştır. Ölçeğin Türkçe formunun geçerlilik ve güvenilirlik çalışması İlhan ve Çetin (2014) ve Şahin ve diğerleri (2013) tarafindan yapılmıştır. Ölçekte güdüsel (Farklı kültürden insanlarla iletişim kurmaktan keyif alır), davranışsal (Farklı kültürden insanlarla iletişimde, sözsüz ifade biçimlerinde değişiklik yapar), bilişsel (Farklı kültürlerin sanat dalları hakkında bilgi sahibidir) ve biliş üstü (Kültürlerarası ilişkilerinde, farklı kültürlere yönelik bilgilerini kullanır) alt boyutlarını ölçen dörder ifade bulunmaktadır. 160 kişiden elde edilen verilerle ölçeğe uygulanan güvenilirlik analizi yüksek bir alfa değeri $(0,96)$ vermiştir. Alt boyutlarının güvenilirlik analizi sonuçları sırasıyla davranışsal $(\alpha=.92)$, bilişsel $(\alpha=.92)$, biliş üstü $(\alpha=$ $.91)$ ve güdüsel $(\alpha=.91)$ boyutlar için yüksek alfa değeri sonuçlarına ulaşılmıştır.

3.2.2. Örgütsel Sinisizm Ölçeği: Araştırmanın bağımlı değişkeni olan örgütsel sinisizmi ölçmek üzere Brandes, Dharwadkar ve Dean (1999) tarafından geliştirilen 14 maddelik ölçek kullanılmıştır. Ölçeğin Türkçe geçerlilik ve güvenilirliği Karacaoğlu ve İnce (2012) tarafindan yapılmıştır. Ölçekte duygusal (Çalıştığım işletmeyi düşündükçe hiddetlenirim), davranışsal (Başkaları ile çalıştığım işletmedeki uygulamaları ve politikaları eleştiririm), bilişsel (Çalıştı̆̆ım işletmede, söylenenler ile yapılanların farklı olduğuna inanıyorum) sinisizm alt boyutlarını ölçen ifadeler bulunmaktadır. 160 kişiden elde edilen verilerle ölçeğe uygulanan güvenilirlik analizi yüksek bir alfa değeri $(0,92)$ vermiştir. Alt boyutlarının güvenilirlik analizi sonuçları sırasıyla duygusal $(\alpha=.92)$, bilişsel $(\alpha=.89)$ ve davranışsal $(\alpha=.81)$ boyutları için yüksek alfa değeri sonucu vermiştir.

3.3.3. Farklılık İklimi Algısı Ölçeği: Araştırmanın ara değişkeni olan farklılık iklimi algısını ölçmek 
Tablo 3. Farklılık İklimi Algısı Faktör Analizi Sonuçları

\begin{tabular}{|c|c|c|c|c|}
\hline Faktörūn Adı & Soru ifadesi & $\begin{array}{c}\text { Faktör } \\
\text { Aăırlikları }\end{array}$ & $\begin{array}{c}\text { Faktörün } \\
\text { Açiklayicaloğ! (\%) }\end{array}$ & Güvenilirlik \\
\hline \multirow{10}{*}{$\begin{array}{l}\text { Çalusma Grubu ve } \\
\text { Örgütsel Faktör }\end{array}$} & 2)Bu isverinde ęitim, kariver ve terfi konularinda bana egit davranilmaktadir. & 0,856 & \multirow{10}{*}{49,150} & \multirow{10}{*}{0,926} \\
\hline & 11)Yöneticilerim astlarinin kisisel farkliliklarina ve pozisyonlarina bakmaksızin tüm & 0,832 & & \\
\hline & $\begin{array}{l}\text { Salişanlara saygilı davranir. } \\
\text { 6)Yonneticim ve takım liderlerim sorunların sozoulme sürecine grubun tüm üyelerini dshil }\end{array}$ & 0,819 & & \\
\hline & eder. & 0,814 & & \\
\hline & 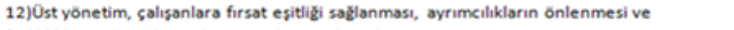 & 0,804 & & \\
\hline & farklihklarıin yönetilmesi konusunda tam destek verir. & 0,800 & & \\
\hline & 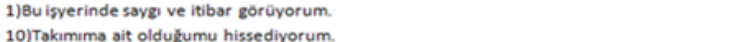 & 0,764 & & \\
\hline & 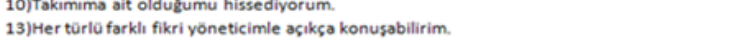 & 0,704 & & \\
\hline & 15)Kurum kültürû değisime açıktır. & 0.651 & & \\
\hline & 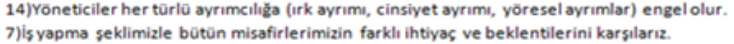 & 0,582 & & \\
\hline \multirow[t]{4}{*}{ Bireysel Faktör } & $\begin{array}{l}\text { 3) İverinde, insanların cinsiyeti, dini, yöresi, bedenselengeli gibi farkliliklarıyla ilgili hos } \\
\text { olmayan sakalar duyuyorum. } \\
\text { 4)isverimde dig̈er insanların ayrımcilik, taciz ve zorbaliklarına sahsen maruz kaldım. }\end{array}$ & $\begin{array}{l}0,854 \\
0,854\end{array}$ & \multirow{4}{*}{$\begin{array}{l}0,899 \\
\text { Ki kare }\end{array}$} & 0,673 \\
\hline & & $\begin{array}{l}\text { Toplam } \\
\text { KMO }\end{array}$ & & \\
\hline & & Barlett Testi & & $\begin{array}{l}1102,333 \\
66\end{array}$ \\
\hline & & & & 0,000 \\
\hline
\end{tabular}

üzere Bean, Sammartino, O'flynn, Lau ve Nicholas (2001) tarafından geliştirilen 15 maddelik ölçek kullanılmıştır. Ölçeğin Türkçe geçerliliği ve güvenilirliği Aksu (2008) tarafından yapılmıştır. Ölçekte bireysel faktörler (İ̧ yerimde diğer insanların ayrımcllik, taciz ve zorbalıklarına şahsen maruz kaldım), çalışma grubu faktörleri ve örgütsel faktörler(Bu işyerimde eğitim, kariyer ve terfi konularında bana eşit davranılmaktadır) alt boyutlarını ölçen beşer ifade bulunmaktadır. 160 kişiden elde edilen verilerle ölçeğe uygulanan güvenilirlik analizi yüksek bir alfa değeri $(0,90)$ vermiştir. Alt boyutlarının güvenilirlik analizi sonuçları sırasıyla bireysel faktörler $(\alpha=.67)$ ve çalışma grubu faktörü ve örgütsel faktörler $(\alpha=.93)$ için yükssek alfa değerleri bulgulanmıştır.

3.3.4. Gelişime Açıklık Ölçeği: Araştırmanın düzenleyici değişkeni olan çalışanın gelişime açıklık kişilik özelliğini ölçümlemek üzere Goldberg (1993) tarafından geliştirilen 44 ifadeli Beş Faktör Kişilik Envanterinden gelişime açıklık kişilik özelliğini ölçen (hayal gücü kuvvetli, yaraticl, sanat ve estetiğe önem veren) 10 ifade kullanılmıştır. Ölçek maddelerinin çevirisi çalışmanın araştırmacıları tarafindan yapılmıştır, geçerlilik analizleri sonucunda tek faktörlü yapı doğrulanmıştır. Gelişime açılık ölçeğinin güvenilirliği çalışmamızda $(\alpha=\quad .82)$ olarak hesaplanmıştır.

\section{BULGULAR}

\subsection{Faktör Güvenilirlik Analizleri}

Yöneticinin algılanan kültürel zekâsı ölçeği için yapılan temel bileşenler analizi kullanılarak yapılan faktör analizinde $(\mathrm{KMO}=0,93$; Barlett Küresellik Testi $=2737,22 ; \mathrm{p}<, 001)$ açıklanan toplam varyans
$\% 77,58$ olup ifadeler dört faktör altında gruplanmıştır. Liderin kültürler arası ortamlarda kendini o kültüre uyarlaması için harcadığı enerjiyi içeren ifadelerin biraya toplandığ 1 birinci faktör "güdüsel kültürel zekâ"; diğer kültürlerden insanlarla iletişim kurarken uygun sözlü ve sözsüz ifadeleri kullanabilme kabiliyetini içeren ifadelerin bir araya toplandığ 1 ikinci faktör "davranışsal kültürel zekâ"; kültürler farklılıklar ve benzerlikler ile ilgili bilgi sahibi olmayı içeren ifadelerin bir araya toplandığı üçüncü faktör "bilişsel kültürel zekâ"; kültürel olarak farklı deneyimleri duyumsamayı içeren ifadelerin bir araya toplandığ 1 dördüncü faktör "üst bilişsel kültürel zekâ" olarak isimlendirilmiştir (Bkz. Tablo 1).

Örgütsel sinisizm ölçeği için yapılan faktör analizinde $\quad(\mathrm{KMO}=0,90 ; \quad$ Barlett Küresellik Testi=1660,48; $\mathrm{p}<, 001)$ açıklanan toplam varyans $\% 71,58$ olup ifadeler üç faktör altında gruplanmıştır. Çalışanın örgüte karşı olumsuz duygulanım ifadelerini içeren birinci faktör "duygusal sinisizm"; çalışanın örgüte karşı olumsuz yönde eleştiri ifadelerini içeren ikinci faktör "davranışsal sinisizm"; çalışanın örgütün bütünlüğünün eksik olduğuna dair inanç ifadelerini içeren üçüncü faktör "bilişsel sinisizm" olarak isimlendirilmiştir (Bkz. Tablo 2).

Farklılık iklimi algısı ölçeği için yapılan faktör analizinde $\quad(\mathrm{KMO}=0,90$; Barlett Küresellik Testi=1102,33; $<<, 001)$ açıklanan toplam varyans $\% 63,87$ olup ifadeler iki faktör altında gruplanmıştır. Çalışma ortamındaki iklimi ve ilişkileri ile örgütün farklılığa karşı tutumu ve tepkisi ifadelerini içeren birinci faktör "çalışma grubu ve örgütsel faktör"; çalışanların iş ortamındaki farlılık ile ilgili deneyim ifadelerini içeren ikinci faktör "bireysel faktör" olarak isimlendirilmiştir(Bkz. Tablo 3). 
Tablo 4. Gelișime Açıklık Faktör Analizi Sonuçları

\begin{tabular}{|c|c|c|c|c|}
\hline Faktörün Adı & Soru ifadesi & $\begin{array}{c}\text { Faktör } \\
\text { Ağırlıkları }\end{array}$ & $\begin{array}{c}\text { Faktörün } \\
\text { Açıklayıclloğ1 (\%) }\end{array}$ & Güvenilirlik \\
\hline & 1)Orijinal, farklı fikirler ortaya koyan & & 45,185 & \\
\hline & 2)Pek çok konuya merak duyan & & 11,900 & \\
\hline & 3)Hünerli, etraflica dūşūnen & & 10,491 & \\
\hline & 4)Hayal gũcũ kurvetli & & 9,288 & \\
\hline & 5)Yaratici & & 7,759 & 0,819 \\
\hline & 6)Sanat ve estetiğe önem veren & & 6,521 & \\
\hline & 8)Fikirlerle oynamayı seven & & 5,777 & \\
\hline & 10)Sanat, müzik ya da edebiyat alanlarinda kültürel birikime sahip & & 3,079 & \\
\hline & & Toplam & & \\
\hline & & кMO & 0,803 & \\
\hline & & Barlett Testi & Ki kare & 394,498 \\
\hline & & & sd & 28 \\
\hline
\end{tabular}

Çalışanın gelişime açıklık ölçeği için yapılan faktör analizinde $\quad(\mathrm{KMO}=0,80)$; Barlett Küresellik Testi394.498; $\mathrm{p}<, 001)$ açıklanan toplam varyans $\% 45.19$ olup ifadeler tek faktör altında gruplanmıştır(Bkz. Tablo 4).

\subsection{Hipotez Testleri ve Regresyon Analizleri}

Çalışanın farklılık iklimi algısının yöneticinin algılanan kültürel zekâsı ile örgütsel sinisizm arasında ara değişken rolü üstlenip üstlenmediğini test etmek üzere üç aşamalı regresyon analizi uygulanmıştır. Birinci aşamada, bağımsız değişkenin ara değişken üzerindeki katkısına, ikinci adımda bağımsız değişkenin bağımlı değişken üzerindeki katkısına, son adımda da bağımsız değişken ile beraber ara değişkenin bağımlı değişken üzerindeki katkıları test edilmiştir. Ara değişken etkisinin bulunması için, regresyon analizinin son adımında bağımsız değişkenin bağımlı değissken üzerindeki anlamlı etkisinin, ikinci adımdaki anlamlı etkisine göre kaybolması ya da azalması gerekmektedir (Baron ve Kenny, 1986). Birinci aşamada yöneticinin algılanan kültürel zekâsının çalışanın farklılık iklimi algısı üzerindeki katkısı test edilmiştir $(\beta=.61, \mathrm{p}<.001)$. İkinci aşamada, liderin algılanan kültürel zekâsının örgütsel sinisizm üzerindeki katkısı incelenmiştir ( $\beta$ $=-.40, \mathrm{p}<.001)($ Bkz. Tablo 5).

Üçüncü aşamada, yöneticinin algılanan kültürel zekâsı ile beraber çalışanın farklılık iklimi algısının örgütsel sinisizm üzerindeki katkıları test edilmiştir. Tablo 6'da sunulduğu gibi çalışanın farklılık iklimi algıs1 dâhil edildiğinde yöneticinin kültürel zekâsının örgütsel sinisizm üzerinde, ikinci aşamada elde edilmiş olan, anlamlı katkısı kaybolmuştur. Çalışanın farklılık iklimi algısının örgütsel sinisizm üzerindeki katkısı oldukça anlamlı çıkmışıır $(\beta=-66, p<.001)$. Ayrıca, Sobel Testi analizi çalışanın farklılık iklimi algısının $(z=-8.95$, $p<0.000)$ liderin algılanan kültürel zekâsı ile örgütsel sinisizm arasında aracı değişken olabileceğini istatistiksel olarak anlamlı göstermektedir (Sobel, 1982). Bu sonuç ilk hipotezi doğrular niteliktedir.

Çalışanın gelişime açıklığının, yöneticinin algılanan kültürel zekâsı ve çalışanın farklılık iklimi algısı arasında şartlı değişken olarak rol oynayıp oynamadığını test etmek amacıyla analizler yapılmış ve yöneticinin algılanan kültürel zekâsının çalışanlardan gelişime açıklığı yüksek olanların,

Tablo 5. Yöneticinin Algılanan Kültürel Zekâsının Çalıșanın Farklılık İklimi Algısı ve Örgütsel Sinisizm Üzerindeki Katkısı

\begin{tabular}{|c|c|c|c|c|c|c|c|c|c|}
\hline & \multirow{2}{*}{\multicolumn{4}{|c|}{$\begin{array}{c}\text { 1.Aşama } \\
\text { Ara Değişken }\end{array}$}} & \multicolumn{4}{|c|}{ 2.Aşama } \\
\hline & & & & & & \multicolumn{4}{|c|}{ Bağımlı Değișen } \\
\hline & & \multicolumn{4}{|c|}{ Çalışanın Farklılık İklimi Algısı } & \multicolumn{4}{|c|}{ Örgütsel Sinisizm } \\
\hline & & $\mathrm{R}$ & $\mathrm{R}^{2}$ & $\mathrm{~F}$ & $\beta$ & $\mathrm{R}$ & $\mathrm{R}^{2}$ & $\mathrm{~F}$ & $\beta$ \\
\hline $\begin{array}{l}\text { B.siz } \\
\text { Değișken }\end{array}$ & $\begin{array}{l}\text { Yön. } \\
\text { Alg. } \\
\text { Kült. } \\
\text { Zekâ. }\end{array}$ & ,608 &, 370 & $92,638 * * *$ &, $608 * * *$ & ,401 &, 161 & $30,274^{* * * *}$ &,$- 401^{* * * *}$ \\
\hline
\end{tabular}


Tablo 6. Yöneticinin Algılanan Kültürel Zekâsı ve Çalıșanın Farklılık İklimi Algısının Örgütsel Sinisizm Üzerindeki Katkıları

\begin{tabular}{|c|c|c|c|c|c|}
\hline & & \multirow{2}{*}{\multicolumn{4}{|c|}{$\begin{array}{c}\text { 3.Așama } \\
\text { Bağımlı Değișken }\end{array}$}} \\
\hline & & & & & \\
\hline & & \multicolumn{4}{|c|}{ Örgütsel Sinisizm } \\
\hline & & $\beta$ & $\mathrm{R}$ & $\mathrm{R}^{2}$ & $\mathrm{~F}$ \\
\hline \multirow[t]{2}{*}{$\begin{array}{l}\text { B.sız } \\
\text { Değişken }\end{array}$} & $\begin{array}{l}\text { Yön. } \\
\text { Alg. } \\
\text { Kült. Zekâsı }\end{array}$ &,- 001 n.s. & \multirow[t]{2}{*}{660} & \multirow[t]{2}{*}{,436 } & \multirow[t]{2}{*}{$60,650^{* * * *}$} \\
\hline & $\begin{array}{l}\text { Çalışanın } \\
\text { Farklılık } \\
\text { İklim Algısı }\end{array}$ &,$- 661 * * *$ & & & \\
\hline
\end{tabular}

gelişime açıklığı düşük olanlara göre, farklılık iklimi algısını arttırıp arttırmadığı incelenmiştir. Analizler sonucunda çalışanın gelişime açıklık derecesinin yöneticinin algılanan kültürel zekâsı ve çalışanın farklılık iklimi algısı arasında şartlı değişken rolü doğrulanmamıştır. Bu sonuç ikinci hipotezimizi desteklememektedir.

\section{SONUÇ VE ÖNERİLER}

$\mathrm{Bu}$ araştırmanın birinci hipotezi, yazında yer alan kültürel zekâ ile farklılık iklimi algısı arasındaki ilişkiye 1şık tutacak bulgulara (örn. Levy-Leboyer, 2004; Deng ve Gibson, 2008) ve farklılık iklimi algısı ile örgütsel sinisizm arasındaki ilişkiye dair bulgulara (örn. Goyal ve Shrivastava, 2013, Chrobot-Mason ve Aramovich, 2013) istinaden kurulmuştur. Liderin algılanan kültürel zekâsındaki artışın, algılanan farklılık ikliminin ara değişken rolü yardımıyla örgütsel sinisizmi düşürdüğü bulgulanmıştır. Başka bir deyişle kültürel zekâsı yüksek liderlerin daha olumlu bir farklılık iklimi yaratacakları ve bu durumun örgütsel sinisizmi düşüreceği söylenebilir. Araştırmanın ikinci hipotezi olan yöneticinin algılanan kültürel zekâsı ile farklılık iklimi algısı arasındaki ilişkide çalışanın gelişime açıklık seviyesinin şartlı değişken işlevine sahip olmadığı bulgulanmıştır. $\mathrm{Bu}$ sonuç araştırmanın Türkiye gibi toplulukçu kültürel değerlerinin hakim olduğu bir ülkede yapılmasına bağlanabilir. Schwartz'ın (1992) belirttiği gibi açıklık kültürel bir değerdir. Açıklık ve dışadönüklük gibi kişilik özellikleri batı kültürlerinde daha istenilen özellikler olabilir (Allik and Mc Grae, 2004). Ayrıca, şartlı değişken modelinin $p$ değeri 0.06 ve $\mathrm{R}^{2}$ değeri 0.37 olarak hesaplanmıştır. Dolayısıyla etkileşimsel değerin daha anlamlı çıkması için daha büyük sayıda bir örnekleme ihtiyaç duyulmaktadır (Cohen, 1992).

Farklı kişilik özelliklerine, demografik özelliklere, bilgi ve beceri çeşitliliğine ve kültürel birikime sahip insanlar iş ortamlarında bir arada çalışmaktadır. Gerek şirketlerin bünyesindeki insan kaynaklarındaki çeşitlilik, gerekse küresel rekabette geri kalmamak için hayata geçirilen yeni uygulamalar, oluşan farklılıkların etkili bir şekilde yönetilmesi ihtiyacını doğurmaktadır. İyi yönetilemeyen farklılık iklimi işletmelerde çalışanların adalet duygusunu zedeleyerek örgütsel sinisizme yol açmaktadır. Başka bir deyişle çalışanlarda, kendilerine eşit davranılmadığı ve gelişimlerinin eşit imkânlarla desteklenmediği algısı oluşmakta ve sonucunda çalışan ve örgütlerin performansında düşüş yaşanabilmektedir. Yöneticilerin iş gücü çeşitliliğine yönelik olumlu yaklaşımları; çalışanlar arasındaki farklılıklardan doğabilecek sorunların kişilere ve örgüte yönelik zarar vermeyecek şekilde yönetilmesine ve buna ek olarak bu farklılıkların çeşitli alanlara katkılarını sağlayarak, çeşitliliği kazanca dönüştürmesine ilişkin uygulamalarıyla ilişkilidir. Aynı zamanda, yöneticilerin bu tutumları sayesinde çeşitli yetkinliklere sahip çalışanlar kabul görüp ve mağduriyet hissetmeyeceklerdir. $\mathrm{Bu}$ sonuç da bu çalışmada görüldüğü üzere, olumlu bir farklılık iklimi algısı yaratarak örgüte yönelik sinik tutum ve davranışları azaltmaktadır.

Bu araştırma, Türkiye'de (İstanbul ilinde) farklı kültürden çalışanların bir arada yoğunlukla çalıştığ turizm sektöründe uygulanan bir anket neticesinde kurulan model ile incelenmiştir. Yukarıda da açıklandığı üzere, birinci hipotez kapsamında incelenen liderin algılanan kültürel zekâsındaki artışın, algılanan farklılık ikliminin ara değişken rolü vesilesi ile örgütsel sinisizmi düşürdüğü ortaya çıkmıştır. Ancak ikinci hipotez kapsamında incelenen yöneticinin algılanan kültürel zekâsı ile farklılık iklimi arasındaki ilişkide çalışanın gelişime açık olmasının düzenleyici rol içermediği anlaşıllmıştır.

İstanbul'un kültürel çeşitlilik anlamında Türkiye'nin kozmopolit yapısını yansıttığ 1 ve temsil edebileceği düşünülebilir. Yine de, bu çalışmadaki temel kavramlar ve ilişkiler, Türkiye'de çeşitli 
bölgelerde aynı ya da farklı sektörlerde çalışan insanlarla ölçümlenerek bölgeler ve sektörler arası farklılıklara bakılabilir. Ayrıca, bu kavramlar ve ilişkiler dünyadaki diğer ülkelerde de araştırılarak ülkeler arası farklılıklara ilişkin görüş sağlayabilir. Araştırmanın kısıtları arasında kesitsel araştırma tasarımının kullanılmış olması bulunmaktadır.

Yapılan araştırmanın özgün kuramsal katkısı, özellikle yöneticinin algılanan kültürel zekâs1, farklılık iklimi algısı ve örgütsel sinisizm değişkenlerini ilk defa bütünleşmiş bir teorik model içinde incelemesidir. Gerek bu alandaki boşluğu doldurması, gerekse çoklu kültürlerden çalışanların yoğun olduğu turizm sektöründe veri sağlaması açısından da çalışma önem taşımaktadır. Çalışmanın uygulamadaki katkısı ise, yöneticilerin kültürel zekâ ve farklılıkların yönetimi konularında bilgilendirilmesi ayrıca bu alanlardaki eğitim programlarının insan kaynakları uygulamaları içerisine alınmasını önermesidir. Bu kapsamda, bilişsel yeterlik ve duygusal zekâya ek olarak kültürel zekâ kıstaslarının da işe alım, performans yönetimi ve ödüllendirme süreçlerine dâhil edilmesi, yönetici adaylarının ya da yöneticilerin belirli sürelerle ulusal ya da uluslararası çeşitli projelerde görevlendirilerek geliştirilmesi yararlı olacaktır.

\section{KAYNAKÇA}

Aksu, N. (2008). Örgüt kültürü bağlamında farklılıkların yönetimi ve bir uygulama. (Yayınlanmış doktora tezi). Uludağ Üniversitesi, Bursa.

Allik, J. ve McCrae, R. R. (2004). Toward a Geography of Personality Traits Patterns of Profiles across 36 Cultures. Journal of Cross-Cultural Psychology, 35(1), 13-28.

Allport, G. W. \& Odbert, H. S. (1936). Trait-names: A psycho-lexical study. Psychological Monographs, 47.

Anderson, L. M. \& Bateman, T. S. (1997). Cynicism in the Workplace: Some Causes and Effects. Journal of Organizational Behavior, 18, 449-469.

Ang, S., Dyn, L. V., \& Koh, C. (2006). Personality correlates of the four factor model of cultural intelligence. Group and Organizational Management, 31(1), 100-123.

Ang, S., Dyne, V. L., Koh, C., Ng, K.Y., Templer, K. J., Tay, J. \& Chandrasekar, N. A. (2007). Cultural Intelligence: Its Measurement and Effects on Cultural Judgement and Decision Making, Cultural Adaptation and Task Performance. Management and Organization Review, 3, 335-371.

Baron R. M. \& Kenny, D. A. (1986). The ModeratorMediator Variable Distinction in Social Psychological Research: Conceptual, Strategic, and Statistical Considerations. Journal of Personality and Social Psychology, 51(6), 1173-1182.

Bean, R., Sammartino, A., O'flynn, J., Lau, K., \& Nicholas, S. (2001).Using Diversity Climate Surveys: A Toolkit for Diversity Management. Programme for the Practice of Diversity Management by Department of Immigration and Multicultural Affairs (DIMA) and Australian Centre for International Business (ACIB).

Brandes, P., Dharwadkar, R., \& Dean, J. W. (1999, May). Does Organizational Cynicism Matter? Employee and Supervisor Perspectives on Work Outcomes. Paper Presented at the 36th Annual Meeting of the Eastern Academy of Management, Philadelphia.

Bono, J. E., Boles, T. L., Judge, T. A. \& Lauver, K. J. (2002). The role of Personality in Task and Relationship Conflict. Journal of Personality, 70(3), 1311-1344.

Cattell, R. B. (1946). The description and measurement of personality. Yonkers, NY: World Book.

Chrobot-Mason, D. \& Aramovich, N. (2013). The Psychological Benefit of Creating an Affirming Climate for Workplace Diversity. Group and Organization Management, 38(6), 659-689.

Cohen, J (1992). 'A power primer'. Psychological 
Bulletin, 112, 155-159.

Costa, P. T. Jr. \& McCrae, R. R. (1995). Domains and facets: Hierarchical personality assessment using the Revised NEO Personality Inventory, Journal of Personality Assessment, 64, 21-50.

Cox, T. (1993). Cultural diversity in organizations. San Francisco: Berrett-Koehler Publishers, Inc.

Dean, J. W., Brandes, P. \& Dharwadkar, R. (1998). Organizational Cynicism. Academy of Management Review, 23(2), 341-352.

Deng, L. \& Gibson, P. (2008). A qualitative evaluation on the role of cultural intelligence in cross-cultural leadership effectiveness. International Journal of Leadership Studies, 3, 181-197.

Earley, P.C. \& Ang, S. (2003). Cultural intelligence: individual interactions across cultures. Stanford University Press, Stanford, CA.

Earley, P. C. \& Mosakowski, E. (2004). Cultural Intelligence. Harvard Business Review, 82 (10), 139146. Retrieved from http://home.trginc.com/sites/default/files/TRGResources/Diversity/C ultural\%20Intelligence.pdf

Fiske S. T., \& Taylor S. E. (1991). Social cognition ( $2^{\text {nd }}$ ed.) New York: McGraw-Hill.

Flynn, F. J. (2005). Having an open mind: The impact of openness to experience on interracial attitudes and impression formation. Journal of Personality and Social Psychology, 88 (5), 816-826.

Goldberg, L. R. (1993). The Structure of Phenotypic Personality Traits. American Psychologist, 48, 264.Retrievedfromhttp://projects.ori.org/lrg/PDFs_paper s/Goldberg.Am.Psych.1993.pdf.

Goyal, S. \& Shrivastava, S. (2013). Organizational Diversity Climate: Review of Models and Measurement. Journal of Business Management and Social Sciences Research, 2(5), 55-60.

Homan, A. D., Hollenbeck, J. R., Humphrey, S. E., Knippenberg, D. V., Ilgen, D. R. \& Van Kleef, G. A. (2008). Facing differences with an open mind: Openness to experience, salience of intragroup differences, and performance of diverse work groups. Academy of Management Journal, 51 (8), 1204-1222.

İlhan, M ve Çetin, B. (2014). Kültürel Zeka Ölçeği'nin Türkçe Formunun Geçerlilik ve Güvenilirlik Çalışması. Hacettepe Üniversitesi Eğitim Fakültesi Dergisi, 29(2), 94-114.

Kossek, E. E., \& Zonia, S. C. (1993). Assessing Diversity Climate: A Field Study of Reactions to Employer Efforts to Promote Diversity.Journal of Organizational Behaviour, 14(1), 61-81.
Leung, K.,Ang, S., and Tan, M. L. (2014). Intercultural competence. Annual Review of Organizational Psychology and Organizational Behavior, 1, 489519.

Levy-Leboyer, C. (2004). Cultural intelligence: Individuals interactions across cultures (BookReview). Personnel Psychology, 57 (3), 792794.

Liebert, M. L. \& Spiegler, M. D. (1990). Personality Strategies and Issues. California: Brooks/Cole Publishing Company.

Maznevski, M. L. (1994). Understanding Our Differences: Performance in Decision making Groups with Diverse Members. Human Relations, 47(5), 531553.

McCrae, R. R. \& Costa, P. T. (Jr.) (1985). Openness to experience. In R. Hogan \& W. H. Jones (Eds.), Perspectives in personality, Vol, 1. Greenwich, CT: JAI Press.

Mead, G. H. (1934). The social psychology of George Herbert Mead. A. Strauss (Ed.). Chicago, IL: University of Chicago Press.

Norman, W. T. (1963). Towards an adequate taxonomy of personality attributes: Replicated factor structure in peer nomination personality ratings. Journal of Abnormal and SocialPsychology, 66, 574-583.

Okat, B.(2010). Örgütlerde Farklllıkların Yönetimi ve Farklilık İklimi Kuramsal Bir Yaklaşım. (YayınlanmamışYüksekLisansTezi).Dokuz Eylül Üniversitesi Sosyal Bilimler Enstitüsü, İzmir.

Özler, D. E. \& Atalay, C. G. (2011). A Research to Determine the Relationship between Organizational Cynicism and Burnout Levels of Employees in Health Sector. Business and Management Review, 1(4), 2638.Retrieved from http://www.businessjournalz.org/ articlepdf/bmr1408.pdf

Pugh, S. D., Brief, A. P., Dietz, J., \& Wiley, J. W. (2008). Looking Inside and Out: The Impact of Employee and Community Demographic Composition on Organizational Diversity Climate. Journal of Applied Psychology, 93 (6), 1422-1428.

Schneider, B., \& Reichers, A. E. (1983). On the etiology of climates. Personnel Psychology, 36, 19-39.

Schwartz, S. H. (1992). Universals in the content and structure of values: Theoretical advances and empirical tests in 20 countries. In M. P. Zanna (ed.), Advances in experimental social psychology, New York: Academic Press, 25: 1-65.

Sobel, M. E. (1982). A symptotic intervals for indirect effects in structural equations models. S. Leinhart (Ed.), Sociological methodology içinde (ss. 290-312). San Francisco: Jossey-Bass. 
Sürgevil, O., \& Budak, G. (2008). İşletmelerin Farklılıkların Yönetimi Anlayışına Yaklaşım Tarzlarının Saptanmasına Yönelik Bir Araştırma. Dokuz Eylül Üniversitesi Sosyal Bilimler Enstitüsü Dergisi, 10(4), 65- 96.

Şahin, F. (2011). Liderin Kültürel Zekasının Astların Örgütsel Vatandaşlık Davranışı ile İş Doyumu Üzerine Etkisi. Savunma Bilimleri Dergisi, 10(2), 80104.

Şahin, F., Gürbüz, S., Köksal, O., \& Ercan, Ü. (2013). Measuring Cultural Intelligence in the Turkish Context. International Journal of Selection and Assessment, 21(2), 135-144.

Şahin, F. \& Gürbüz, S. (2012). Kültürel zekâ ve özyeterliliğin görev performansı ve örgütsel vatandaşlık davranışı üzerinde etkisi: Çokuluslu örgüt üzerinde bir uygulama. 'Işs Güç' Endüstri İlişkileri ve Insan Kaynakları Dergisi, 14(2), 123-140.

Thomas, D. C., \& Inkson, K. (2005). Cultural Intelligence: people skills for a global workplace. Consulting to Management, 16 (1).

Tupes, E. C. \& Christal, R. E. (1961). Recurrent personality factors based on trait ratings (USAF ASD Tech. Rep. No. 61-97). Lackland Air Force Base, TX: U.S. Air Force.

Tükeltürk, Ş. A., Perçin, N. Ş. \& Güzel, B. (2009). Örgütlerde Psikolojik Kontrat İhlalleri ve Sinisizm İlişkisi: 4-5 Yıldızlı Otel İşletmeleri Üzerine Bir Araştırma.17.Ulusal Yönetim ve Organizasyon Kongresi Bildiriler Kitabı, 686-691.

Wanous, J. P., Reichers, A. E., \& Austin, J. T. (1994). Organizational Cynicism: An Initial Study. Academy of Management Best Papers Proceedings, 269-273. Doi: 10.5465/AMBPP.1994.10344804. 